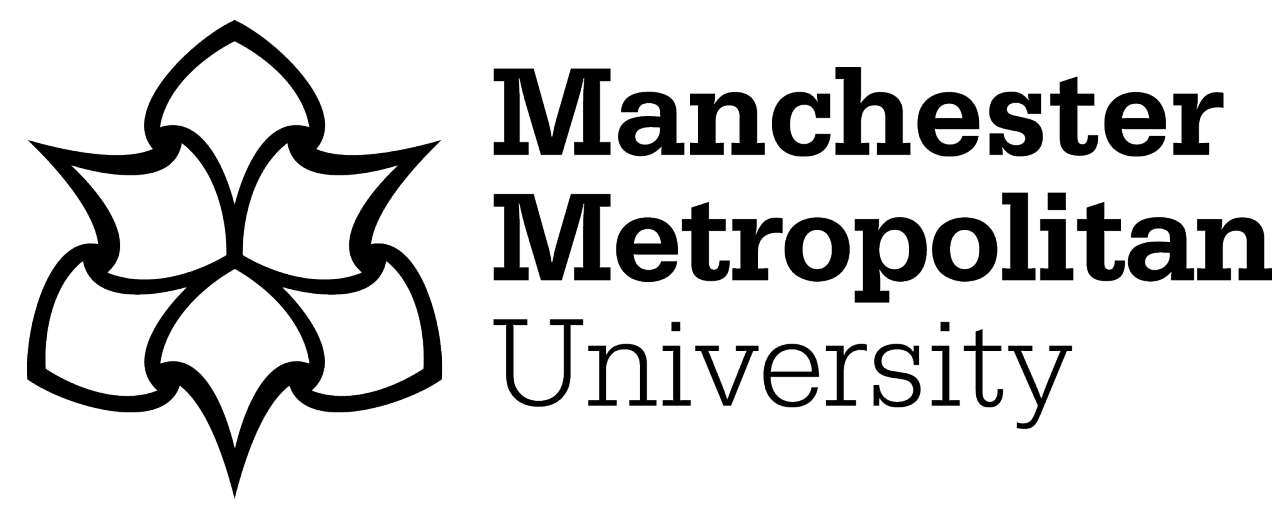

Parry, SL and Simpson, J (2016) How do Adult Survivors of Childhood Sexual Abuse Experience Formally Delivered Talking Therapy? A Systematic Review. Journal of Child Sexual Abuse, 25 (7). pp. 793-812. ISSN 15470679

Downloaded from: https://e-space.mmu.ac.uk/689/

Version: Accepted Version

Publisher: Taylor \& Francis

DOI: https://doi.org/10.1080/10538712.2016.1208704

Usage rights: Creative Commons: Attribution-Noncommercial 4.0

Please cite the published version 
CSA Survivor Experiences of Talking Therapies

\section{How do Adult Survivors of Childhood Sexual Abuse Experience Formally Delivered Talking Therapy? A Systematic Review}

Sarah Parry, Department of Psychology, Manchester Metropolitan University; Jane Simpson, Division of Health Research, Lancaster University.

Correspondence concerning this article should be addressed to Sarah Parry.

Department of Psychology, Faculty of Health, Psychology \& Social Care, Manchester Metropolitan University, Brooks Building, 53 Bonsall Street, Manchester, UK, M15 6GX.. Tel: +44 (0)161 247 5796. Email: s.parry@mmu.ac.uk

\section{Author Biographies:}

Dr Sarah Parry is a clinical psychologist and Senior Lecturer in the Department of Psychology at Manchester Metropolitan University. Her current research interests include exploring how people heal following trauma and the narratives people develop around dissociative experiences. She received her DClinPsy from the University of Lancaster.

Dr Jane Simpson is an academic and clinical psychologist with a significant publication record in the psychology of chronic illness. She is also interested in people's experiences of any care system and the difficulties health care systems have of adapting to the needs of people with different care needs. She is currently Director of Education in the Division of Health Research at Lancaster University.

Submission Date: 04/21/2016

Date of First Review: 05/17/2016

Date of Second Review: 05/23/2016

Date Accepted: 05/23/2016 
CSA Survivor Experiences of Talking Therapies

\begin{abstract}
This systematic review explored how adult survivors of childhood sexual abuse experienced non-specific and trauma-focused talking therapies. Following extensive systematic searches of academic databases, 23 qualitative empirical studies were chosen for review. Using a line-by-line thematic synthesis, four analytical themes developed. These themes were: The Therapeutic Process as a Means for Forming Connections, which discusses therapeutic relationships; Developing a Sense of Self through the Therapeutic Processes, identifying stages of developmental recovery; Therapeutic Lights and Black Holes in the Shadows of CSA, reflecting upon how a history of CSA influenced experiences of therapy; and Healing or Harrowing: connecting with others and first time experiences, exploring what was helpful, hindering, and new throughout the therapeutic journey. Findings related to participants developing new options for interpersonal relationships through the experience of authentic trust and the experiential learning of control and choice.

Recommendations are discussed in relation to developing therapeutic practice and future research.
\end{abstract}

Key words: psychotherapy, therapeutic relationships, trust, safety, reconnecting, control, choices 
CSA Survivor Experiences of Talking Therapies

How do Adult Survivors of Childhood Sexual Abuse Experience Formally Delivered Talking Therapy? A Systematic Review

Abuse can often take multiple forms (Higgins \& McCabe, 2001; Richmond, Elliot, Pierce, Aspelmeier, \& Alexander, 2009) but child sexual abuse (CSA) can have specific and persistent consequences for adult survivors (Ehring, et al., 2014; Price-Robertson, Rush, Wall, \& Higgins, 2013; Ullman, 2015). Indeed, as has been noted, "childhood trauma, particularly sexual abuse, may set in motion chain reactions of trauma across the life cycle...” (Banyard, Williams, \& Siegal, 2001, p.698). Further, Maniglio (2009) demonstrated, through a seminal review of reviews covering 587 studies, how a wide range of adult psychological functioning was profoundly influenced by CSA, for example, in the development of eating disorders, self-injury, and victimization in adulthood.

It has been argued that a significant contributing issue to this range of difficulties is the loss of a belief in the security of key relationships. Children who have experienced sexual abuse and interpersonal violence often lose a sense of trust and safety with others (Briere, 1992), directly affecting interpersonal predictability in relationships. Moreover, a number of empirical studies exploring relationships for people with CSA experiences have found that participants identified difficulties in forging and maintaining relationships (e.g. Kia-Keating, Sorsoli, \& Grossman, 2010; McGregor, Thomas, \& Read, 2006).

The difficulty in forging and maintaining secure relationships in adulthood has been hypothesised to contribute to the challenges faced by survivors of CSA when they attempt to engage in psychotherapy (Olio \& Cornell, 1993). Additionally, a person's sense of self is irrevocably changed through CSA (as discussed extensively in Saha, Chung, \& Thorne, 2011), leading to low self-esteem and often a sense of unworthiness (e.g. Finkelhor, Hotaling, Lewis, \& Smith, 1990), which may also impact the process of seeking and engaging in psychotherapy. Additionally, CSA survivors can experience difficulties regulating their 
emotions, including managing feelings of anger and other potentially overwhelming emotions (Kia-Keating, Sorsoli, \& Grossman, 2010), which may also impact the therapeutic alliance (Lev-Wiesel, 2008; McAlpine \& Shanks, 2010) and thus the therapeutic experience. Indeed, Olio suggests the establishment of an effective therapeutic relationship "is probably the single most important factor" in the successful treatment of adult sexual abuse survivors (1989, p.98). Consequently, as a result of the particular relational difficulties CSA survivors can experience, it is important to understand how survivors experience talking therapies (Chouliara et al., 2012).

In terms of therapeutic modality, CSA survivors have, in some studies, reported that the type of therapy they have received has not influenced whether therapy itself was beneficial (Chouliara et al., 2012; Hetzel-Riggin, Brausch \& Montgomery, 2007; Nelson \& Phillips, 2001). Moreover, a recent meta-synthesis (Draucker et al., 2009) exploring healing for sexual violence survivors concluded that it was understanding experiences, rather than developing positive or adaptive coping strategies, which survivors found helpful. Therefore, it may be that a person's understanding of their experiences through therapy may be more important to the process of healing than trauma resolution or symptom management. However, other empirical studies have suggested that working with a therapist who specialises in trauma is important (e.g. McGregor, Thomas, \& Reid, 2006).

Missing from the present body of research in the area of psychotherapy for CSA survivors is information regarding how survivors who have experienced a range of talking therapies perceive the process of therapy, therapeutic modality, and therapeutic relationship. Understanding what makes therapy helpful and effective for survivors of CSA is particularly important due to the specific challenges survivors may experience in their adult relationships, including the therapeutic relationship (Gill, 2010; Kendall-Tackett, Williams, \& Finkelhor, 2001). Consequently, the aim of the current systematic review was to synthesise qualitative 
CSA Survivor Experiences of Talking Therapies

studies on the experiences of adult survivors of CSA in relation to a range of formally delivered talking therapies including both non-specific and trauma-focused therapies.

\section{Method}

\section{Search Strategy}

A comprehensive list of articles was accumulated from online research databases, including PsycINFO, OneSearch, Academic Search Complete, and PubMed. Search terms included: therap* AND child abuse AND emotional trauma / therap* AND child sexual abuse AND qualitative / therap* AND trauma focussed AND child sexual abuse AND child sexual assault / therap* AND psychotherapy AND child sexual abuse (Limiters: English, $18 y$ rs and older, qualitative, peer-reviewed). In order to refine the included studies for the review, 30 studies were condensed to 24 and then to 23 , depending upon how directly they addressed the research question (Table 1).

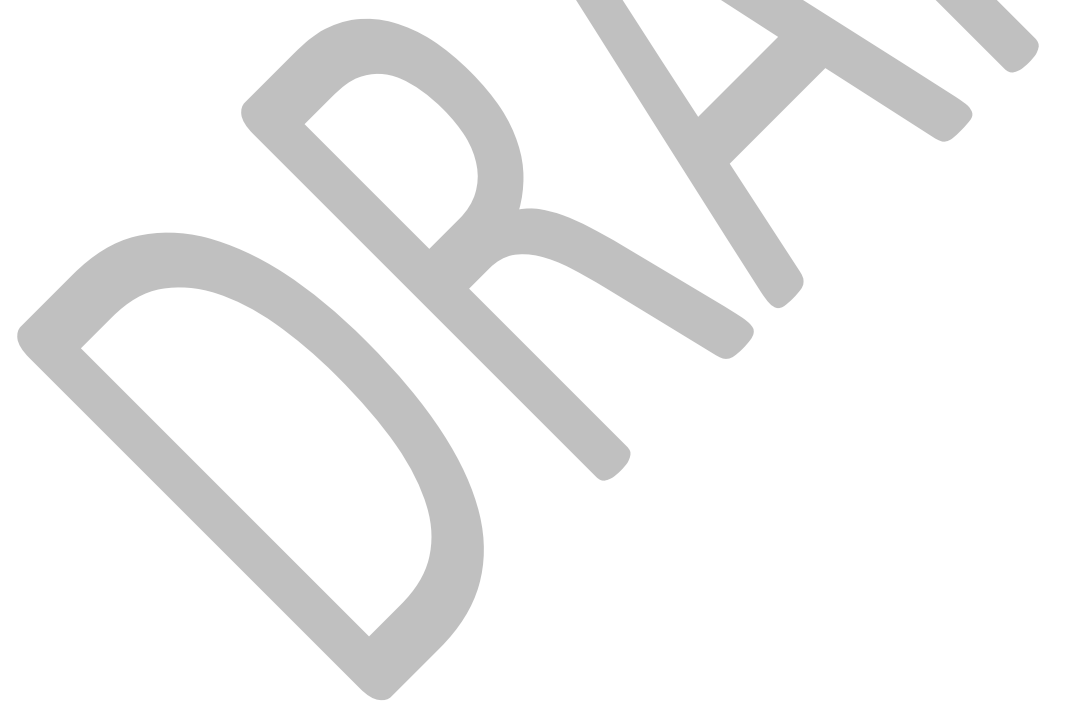


Table 1

Characteristics of included studies

\begin{tabular}{|c|c|c|c|c|c|}
\hline Authors \& Date & Participants & Data Collection & Analysis & Epistemology & Country \\
\hline $\begin{array}{l}\text { Anderson \& } \\
\text { Hiersteiner (2008) }\end{array}$ & $\begin{array}{l}2 \mathrm{M}, 25 \mathrm{~F} \\
\text { Mage }= \\
43.6\end{array}$ & $\begin{array}{l}\text { Convenience sampling and } \\
\text { group interviews }\end{array}$ & $\begin{array}{l}\text { Grounded theory - } \\
\text { categorical-conten } \\
\text { approach }\end{array}$ & $\begin{array}{l}\text { Not declared, } \\
\text { appears } \\
\text { constructionist }\end{array}$ & USA \\
\hline $\begin{array}{l}\text { Arias \& Johnson } \\
(2013)\end{array}$ & $\begin{array}{l}0,10 \mathrm{~F}, \\
\text { Mage }=49\end{array}$ & $\begin{array}{l}\text { Semi-structured individual } \\
\text { interviews }\end{array}$ & Grounded theory & Constructionist & USA \\
\hline $\begin{array}{l}\text { Brown, } \\
\text { Kallivayalil, } \\
\text { Mendelsohn, \& } \\
\text { Harvey (2012) }\end{array}$ & $\begin{array}{l}2 \mathrm{M}, 18 \mathrm{~F} \\
\text { Mage }=32\end{array}$ & $\begin{array}{l}\text { Semi-structured interview } \\
\text { (The Multidimensional } \\
\text { Trauma Recovery and } \\
\text { Resiliency Interview and } \\
\text { Scale) }\end{array}$ & & Constructionist & Canada \\
\hline $\begin{array}{l}{ }^{1} \text { Chouliara et al. } \\
\text { (2011) }\end{array}$ & $\begin{array}{l}0 \mathrm{M}, 13 \mathrm{~F} \\
\text { Mage }=40\end{array}$ & Semi-st & & $\begin{array}{l}\text { Not explicitly } \\
\text { declared, although } \\
\text { reference is made } \\
\text { to the "realist } \\
\text { ontology of the } \\
\text { social cognitive } \\
\text { paradigm" within } \\
\text { IPA }\end{array}$ & Scotland \\
\hline $\begin{array}{l}\text { Edmond, Sloan, \& } \\
\text { McCarty (2004) }\end{array}$ & $\begin{array}{l}0 \mathrm{M}, 38 \mathrm{~F} \\
\text { Mage }=35\end{array}$ & $\begin{array}{l}\text { Individual interviews (w } \\
\text { quant measures also) }\end{array}$ & Thematic analysis & $\begin{array}{l}\text { Not declared - } \\
\text { appears } \\
\text { constructionist }\end{array}$ & USA \\
\hline $\begin{array}{l}\text { Grossman, Sorsoli, } \\
\text { \& Kia-Keating } \\
(2006)\end{array}$ & $\begin{array}{l}16 \mathrm{M}, 0 \mathrm{~F} \\
\text { Mage }= \\
42.5\end{array}$ & $\begin{array}{l}\text { Individual semi structured } \\
\text { interview (around } 5 \text { hours } \\
\text { each) }\end{array}$ & $\begin{array}{l}\text { Thematic content } \\
\text { analysis }\end{array}$ & $\begin{array}{l}\text { Appears largely } \\
\text { realist }\end{array}$ & USA \\
\hline
\end{tabular}

${ }^{1}$ Only survivor quotes were used in the review. 


\begin{tabular}{|c|c|c|c|c|c|}
\hline *Harper (2006) & $\begin{array}{l}3 \mathrm{M}, 8 \mathrm{~F} \\
\text { Mage }=40\end{array}$ & $\begin{array}{l}\text { Individual interviews with } \\
\text { follow-up questionnaires }\end{array}$ & Grounded theory & $\begin{array}{l}\text { Not declared - } \\
\text { appears } \\
\text { constructionist }\end{array}$ & Canada \\
\hline $\begin{array}{l}\text { Harper, Stalker, } \\
\text { Palmer, \& } \\
\text { Gadbois (2008) }\end{array}$ & $\begin{array}{l}5 \mathrm{M}, 25 \mathrm{~F} \\
\text { Mage }= \\
40.8\end{array}$ & Individual interviews & $\begin{array}{l}\text { Constant comparative } \\
\text { method for codes } \\
\text { followed by } \\
\text { ethnography }\end{array}$ & $\begin{array}{l}\text { Not declared - } \\
\text { appears } \\
\text { constructionist in } \\
\text { most parts }\end{array}$ & Canada \\
\hline $\begin{array}{l}\text { Kallivayalil, } \\
\text { Levitan, Brown, \& } \\
\text { Harvey (2013) }\end{array}$ & $\begin{array}{l}1 \mathrm{M}, 13 \mathrm{~F} \\
\text { Mage }=42\end{array}$ & Semi-structured interviews & $\begin{array}{l}\text { Grounded theory } \\
\text { approach to the } \\
\text { analysis of narrative } \\
\text { accounts }\end{array}$ & $\begin{array}{l}\text { Not declared - } \\
\text { appears } \\
\text { constructionist }\end{array}$ & USA \\
\hline $\begin{array}{l}\text { Kia-Keating, } \\
\text { Sorsoli, \& } \\
\text { Grossman (2010) }\end{array}$ & $\begin{array}{l}16 \mathrm{M}, 0 \mathrm{~F} \\
\text { Mage }= \\
41.5\end{array}$ & Semi-structured int & $\begin{array}{l}\text { Grounded the } \\
\text { approach }\end{array}$ & $\begin{array}{l}\text { Not declared - } \\
\text { appears } \\
\text { constructionist }\end{array}$ & USA \\
\hline Koehn (2007) & $\begin{array}{l}0 \mathrm{M}, 50 \mathrm{~F} \\
\text { Mage }=37\end{array}$ & Individual it & Critical incident & $\begin{array}{l}\text { Not declared - } \\
\text { appears critical } \\
\text { realist }\end{array}$ & USA \\
\hline Lev-Wiesel (2000) & $\begin{array}{l}15 \mathrm{M}, 37 \mathrm{~F} \\
\text { Mage }=38\end{array}$ & $\begin{array}{l}\text { Individual quasi-open ended } \\
\text { interviews and quantitative } \\
\text { quality of life questionnaire }\end{array}$ & $\begin{array}{l}\text { Narrative (narrative } \\
\text { biographical } \\
\text { interviews) }\end{array}$ & $\begin{array}{l}\text { Not declared, } \\
\text { discusses } \\
\text { constructs and } \\
\text { reconstructs }\end{array}$ & Israel \\
\hline $\begin{array}{l}\text { McGregor, } \\
\text { Thomas, \& Reid } \\
\text { (2006) }\end{array}$ & $\begin{array}{l}0 \mathrm{M}, 20 \mathrm{~F} \\
\text { Mage }=38\end{array}$ & & $\begin{array}{l}\text { Grounded theory } \\
\text { approach }\end{array}$ & $\begin{array}{l}\text { Not declared - } \\
\text { appears critical } \\
\text { realist }\end{array}$ & New Zealand \\
\hline $\begin{array}{l}\text { O'Brien, } \\
\text { Henderson, \& } \\
\text { Bateman (2007) }\end{array}$ & $\begin{array}{l}\text { 0M, 14F, } \\
\text { Mage }= \\
\text { unknown }\end{array}$ & $\begin{array}{l}\text { Focus groups and individual } \\
\text { interviews }\end{array}$ & Thematic analysis & $\begin{array}{l}\text { Not declared, } \\
\text { realist aspects }\end{array}$ & Australia \\
\hline $\begin{array}{l}\text { Palmer, Stalker, } \\
\text { Gadbois, \& Harper } \\
(2004)\end{array}$ & $\begin{array}{l}5 \mathrm{M}, 25 \mathrm{~F} \\
\text { Mage }= \\
40.8 \\
\end{array}$ & $\begin{array}{l}\text { Individual interviews after } \\
\text { completing an inpatient post- } \\
\text { trauma (CSA) programme. }\end{array}$ & $\begin{array}{l}\text { Grounded theory } \\
\text { informed constant } \\
\text { comparative method }\end{array}$ & $\begin{array}{l}\text { Not declared - } \\
\text { appears critical } \\
\text { realist }\end{array}$ & Australia \\
\hline
\end{tabular}




\begin{tabular}{|c|c|c|c|c|c|}
\hline $\begin{array}{l}\text { Palmer, Stalker, } \\
\text { Harper, \& Gadbois } \\
(2007)\end{array}$ & $\begin{array}{l}5 \mathrm{M}, 25 \mathrm{~F} \\
\text { Mage }= \\
40.8\end{array}$ & Individual interviews & $\begin{array}{l}\text { Grounded theory } \\
\text { informed constant } \\
\text { comparative method }\end{array}$ & $\begin{array}{l}\text { Not declared - } \\
\text { appears critical } \\
\text { realist }\end{array}$ & Australia \\
\hline $\begin{array}{l}\text { Parker, Fourt, } \\
\text { Langmuir, Dalton, } \\
\text { \& Classen (2007) }\end{array}$ & $\begin{array}{l}0 \mathrm{M}, 7 \mathrm{~F}, \\
\text { Mage }=38\end{array}$ & $\begin{array}{l}\text { Completed WRAP at least six } \\
\text { months prior to semi- } \\
\text { structured interviews. }\end{array}$ & & $\begin{array}{l}\text { Not declared - } \\
\text { appears critical } \\
\text { realist }\end{array}$ & Canada \\
\hline $\begin{array}{l}\text { Phelps, } \\
\text { Friedlander, \& } \\
\text { Enns (1997) }\end{array}$ & $\begin{array}{l}0 \mathrm{M}, 11 \mathrm{~F} \\
\text { Mage }= \\
41.7\end{array}$ & $\begin{array}{l}\text { Individual semi-structured } \\
\text { interviews }\end{array}$ & $\begin{array}{l}\text { Pattern coding leading } \\
\text { to thematic analysis }\end{array}$ & $\begin{array}{l}\text { Not declared - } \\
\text { appears largely } \\
\text { constructionist }\end{array}$ & USA \\
\hline $\begin{array}{l}\text { Phillips \& Daniluk } \\
\text { (2004) }\end{array}$ & $\begin{array}{l}0 \mathrm{M}, 7 \mathrm{~F}, \\
\text { Mage }= \\
43.5\end{array}$ & $\begin{array}{l}\text { Individual interviews with a } \\
\text { focus on self-identity and } \\
\text { healing. }\end{array}$ & & $\begin{array}{l}\text { Not declared - } \\
\text { appears } \\
\text { constructionist }\end{array}$ & Canada \\
\hline $\begin{array}{l}\text { Saha, Chung, \& } \\
\text { Thorne (2011) }\end{array}$ & $\begin{array}{l}0 \mathrm{M}, 4 \mathrm{~F} \\
\text { Mage }= \\
47.5\end{array}$ & $\begin{array}{l}\text { Narrative interviews. 1) life- } \\
\text { story interview; 2) recovery- } \\
\text { story interview; 3) semi- } \\
\text { structured interview which } \\
\text { aimed to explore } \\
\text { participants' understanding of } \\
\text { how their selves evolved after } \\
\text { their therapy } \\
\text { experiences. }\end{array}$ & Narrative analysis & $\begin{array}{l}\text { Not declared - } \\
\text { appears } \\
\text { constructionist }\end{array}$ & $\begin{array}{l}\text { South-west } \\
\text { England }\end{array}$ \\
\hline $\begin{array}{l}\text { Stige, Rosenvinge, } \\
\& \text { Træn (2013) }\end{array}$ & $\begin{array}{l}0 \mathrm{M}, 13 \mathrm{~F} \\
\text { Mage }=39\end{array}$ & $\begin{array}{l}\text { Interviews were interviewed } \\
\text { within three months of } \\
\text { completing the therapy group. }\end{array}$ & $\begin{array}{l}\text { Hermeneutical- } \\
\text { phenomenological } \\
\text { approach - focus } \\
\text { personal accounts } \\
\text { whilst recognising } \\
\text { researcher bias. }\end{array}$ & $\begin{array}{l}\text { Not declared - } \\
\text { appears critical } \\
\text { realist }\end{array}$ & Norway \\
\hline
\end{tabular}


CSA Survivor Experiences of Talking Therapies

\begin{tabular}{|c|c|c|c|c|c|}
\hline $\begin{array}{l}\text { Stige, Træen, \& } \\
\text { Rosenvinge (2013) }\end{array}$ & $\begin{array}{l}0 \mathrm{M}, 13 \mathrm{~F} \\
\text { Mage }=39\end{array}$ & $\begin{array}{l}\text { Participants were interviewed } \\
\text { within three months of } \\
\text { completing the therapy group. }\end{array}$ & $\begin{array}{l}\text { Hermeneutical- } \\
\text { phenomenological } \\
\text { approach }\end{array}$ & $\begin{array}{l}\text { Not declared - } \\
\text { appears critical } \\
\text { realist }\end{array}$ & Norway \\
\hline $\begin{array}{l}\text { Tummala-Narra, } \\
\text { Kallivayalil, } \\
\text { Singer, \& } \\
\text { Andreini (2012) }\end{array}$ & $\begin{array}{l}3 \mathrm{M}, 18 \mathrm{~F} \\
\text { Mage }= \\
43.2\end{array}$ & Individual interviews & Grounded Theory & $\begin{array}{l}\text { Not declared - } \\
\text { appears critical } \\
\text { realist }\end{array}$ & USA \\
\hline
\end{tabular}

Andreini (2012)

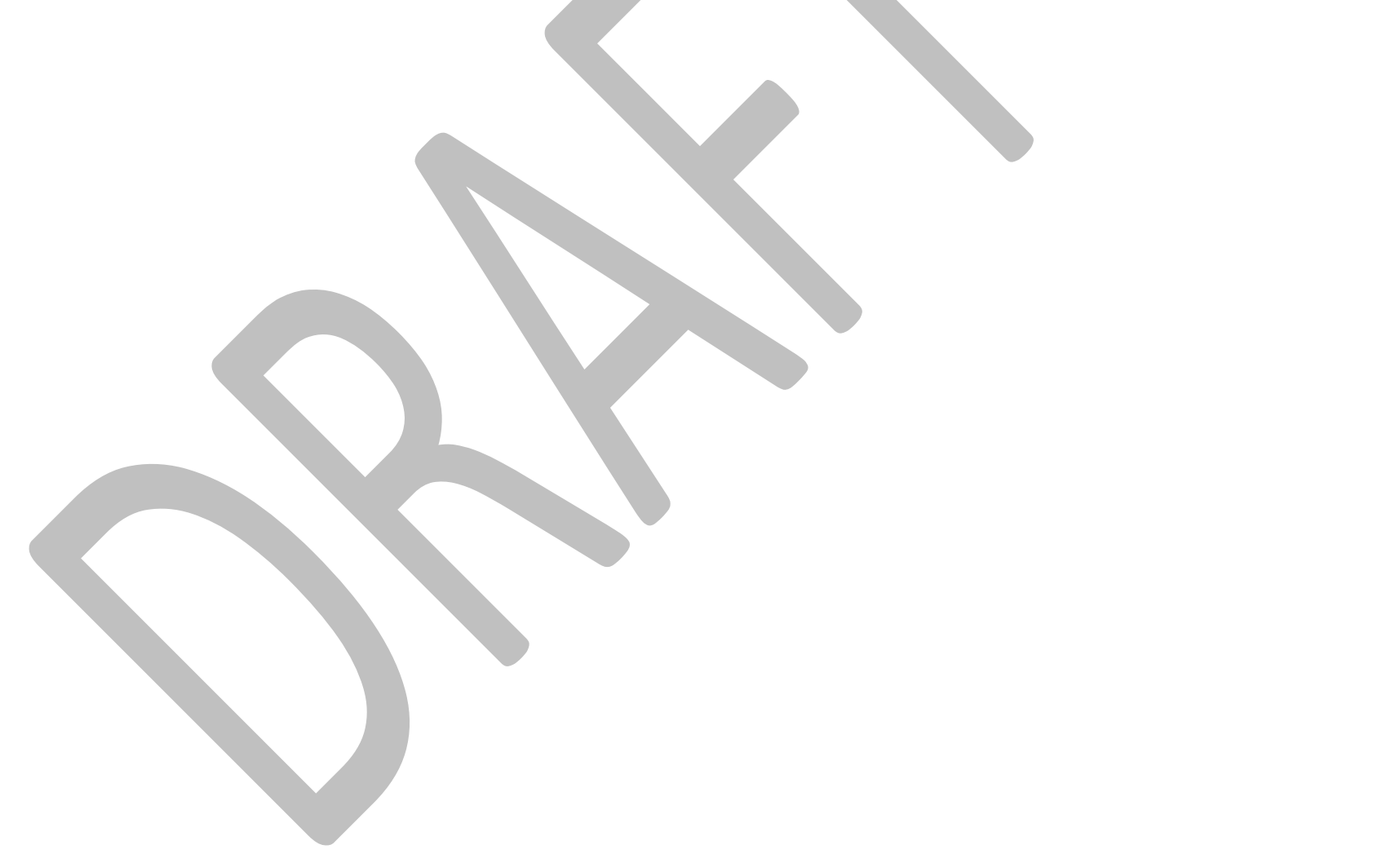


CSA Survivor Experiences of Talking Therapies

\section{Quality Appraisal}

The Critical Appraisal Skills Programme (CASP, 2013) was used as a framework to critique the characteristics of the selected studies due to its relevance to health related research. As recommended by Maniglio (2009), the studies were considered for quality, not inclusion or exclusion, in order to enable the critical appraisal of the findings. Each study was awarded a mark of $0-2$ for each of the 10 items ( 0 if the guidance for that item was not met, 1 if partially met, and 2 if fully met). Eventually, when the scores for each study were combined, each study was scored between 14 and 20 .

\section{Analytic Approach}

Within the current synthesis, enormous variety was evident between the reviewed studies in terms of their approach to data and the level of interpretation of the findings. Therefore, the varying presentation of data required careful consideration, which presented some challenges (Sandelowski, Barroso, \& Voils, 2007). Consequently, the analysis was that of thematic synthesis (Harden \& Thomas, 2008), rather than an ethnographic approach, to dilute the range of interpretation and difference across the studies. The entire results and findings sections of the reviewed papers, not solely quotes, were analysed line-by-line. The exceptions to this rule were the quotes from professional practitioners, which were not included in this synthesis in order to maintain a homogenous approach.

Finally, the first author provided additional interpretation of the results and findings sections, based on the inductive analysis, and synthesised the findings (Gomersall, Madill, \& Summers, 2011; Rice, 2008). Each study was transposed into NVivo10, a computerised qualitative analysis software package used for coding large amounts of data. Following this, the line-by-line inductive thematic synthesis was undertaken. This approach facilitated the interpretation of each element of data into a unifying system of 1,967 codes, which created 295 descriptive themes. Although great care was taken to inductively generate the codes, the 
CSA Survivor Experiences of Talking Therapies

themes generated were subject to the epistemological perspective of critical realism, identified and reflected upon by the authors. The descriptive themes were grouped through a constant comparative method to form 18 preliminary analytical themes and, finally, the four analytical themes of the meta-synthesis, which embodied the inductively synthesised findings of the study, illustrated throughout by quotes pertinent to the main findings. The naming of the themes formed a part of the synthesis and titles developed to encapsulate the meaning of each theme. Finally, once all the studies had been coded, the initial study to be analysed, Kallivayalil, Levitan, Brown, and Harvey (2013), was reviewed again to check its consistency with how it was originally coded.

\section{Thematic Synthesis Findings}

Theme 1: The Therapeutic Process as a Means for Forming Connections - "that's why I related to her . . because she had that reaction." (McGregor, Thomas \& Reid, 2006, p.49).

Interpersonal interactions appeared a crucial first step in the therapeutic process, which was challenging for the majority of participants across the studies. Many participants appeared to attribute their interpersonal difficulties to experiencing abuse.

\section{Theme 1.1: Developing trust in relationships and with oneself}

A number of studies discussed participants' difficulties in developing relationships with others: "I see people as vicious" (Tummala-narra, Kallivayalil, Singer, \& Andreini, 2012, p.644). However, once some relational connections had been made, other healing processes could begin. One participant explained how trusting his therapist had helped him connect with other people: "Trust is a miracle. I've never trusted anybody" (Kia-Keating, Sorsoli, \& Grossman, 2010, p.677-8).

One way in which the therapists were able to develop trust in the relationship was through helping the client feel equal (O’Brien, Henderson, \& Bateman, 2007; Palmer, 
Stalker, Gadbois, \& Harper, 2004); as one client's therapist explained: “I am a person, and you're a person, and we're doing this work together" (Koehn, 2007, p.51). Additionally, empowerment was an important feature, which was discussed in various forms across the studies (e.g. Chouliara et al., 2011; McGregor, Thomas, \& Reid, 2006; Phelps, Friedlander, \& Enns, 1997). In relation to feeling empowered or, conversely, re-victimised, having a sense of control, choice, and direction appeared vital. For example, there were a number of statements recalling how choice could be offered and how that made the participant feel: "she makes sure that I'm in control of everything'" (Harper, Stalker, Palmer, \& Gadbois, 2008, p.369). Participants were also able to see how other people made choices, which helped develop their interpretation of events and ultimately trust themselves: "I am free to choose my way" (Stige, Rosenvinge, \& Træen, 2013, p.425). Some also mentioned that it could be helpful to have suggestions, once trust had been established (Harper, Stalker, Palmer, \& Gadbois, 2008; Phelps, Friedlander, \& Enns, 1997): "if they [clients] knew the solutions they might have found them already" (McGregor, Thomas, \& Reid, 2006, p.52). The choice to undertake therapy was also mentioned: "It was really difficult, but at the same time I wanted to do it" (Stige, Rosenvinge, \& Træen, 2013, p.424).

Developing choice, control, and empowerment is particularly important for CSA survivors as choice and control were so often missing from their childhoods and appeared to directly impact their experience of therapy as adults: "It's my soul. And I don't have to talk about it if I don't want to" (Koehn, 2007, p.49). When choice was not clearly provided for participants, it could be more difficult for the participants to exercise control. For example, one participant reported that not being able to prevent his therapist from self-disclosure was similar to not being able to "stop the abuse": "again you've gone through basically having something forced on you." (Harper, 2006, p.106). 


\section{2: Developing self-trust through therapeutic connections}

Arias and Johnson found that participants were able to develop relational connections when they had the opportunity to share their abuse histories safely, with therapists who displayed "honesty," "competency," "trustworthiness," and "willingness to confront them on their inconsistencies," which seemed to reduce their sense of isolation (2013, p.832). Within the participant accounts was a sense that being believed and not judged was crucial in whether a therapist was trustworthy and worthy enough of hearing their stories (Anderson \& Hiersteiner, 2008; Chouliara et al., 2011; McGregor, Thomas, \& Reid, 2006). Accordingly, one participant described how the therapist: “didn't judge and wasn't shocked. She didn't question whether this was 'the truth.' (O'Brien, Henderson, \& Bateman, 2007, p.4). Trust also seemed to be an intrapersonal experience for some, as one participant explained: "She wasn't scared of me being mad. ... I learned a lot of self-trust in that" (Koehn, 2007, p.50).

In summary, the process of telling stories and having "somebody who listens and believes" (Phelps, Friedlander, \& Enns, 1997, p.325) facilitated bonding intrapersonally and interpersonally. Within the accounts was a sense that participants learnt trust through safely connecting with trustworthy others and then were able to internalise trust, which appeared to soften their perspective on the world around them: "it's [the world] too beautiful to give up and be scared." (Tummala-narra, Kallivayalil, Singer, \& Andreini, 2012, p.644).

\section{3: Tools for developing safety}

In addition to establishing a sense of equality, trust, and safety, participants described some of the explicit tasks their therapists undertook that they found helpful. For example, there were several mentions of therapists normalising the reaction their client was having in response to their traumatic pasts (Edmond, Sloan, \& McCarty, 2004; Palmer, Stalker, Gadbois, \& Harper, 2004). For instance, "I had thought, since I was nine, that I was crazy." (McGregor, Thomas \& Reid, 2006, p.48). Another participant discussed how her therapist 
CSA Survivor Experiences of Talking Therapies

facilitated therapeutic space: "she defused that [potential conflict] by giving me more room... room to express myself.” (Koehn, 2007, p.50). For other participants, their therapist explicitly demonstrated they were listening: "I feel so heard when she says back to me what I'm saying to her" (Phelps, Friedlander, \& Enns, 1997, p.325).

Theme 2: Developing a Sense of Self through the Therapeutic Processes - "it was as if I got hit by my own life! Everything caught up with me!” (Stige, Rosenvinge, \& Træen, 2013, p.1301).

The second theme of this synthesis regards how the participants experienced themselves through therapy, which appeared to be a multi-staged and fluid process. Together, the reviewed studies span a range of the developmental stages and offer an array of insights, encompassing stages of self-awareness and self-healing.

\section{1: An ambiguous sense of self}

Initially, the participants' early stories about engaging with therapy discussed an ambiguous or absent self: "I didn't have myself, a sense of myself as being a child even or a little girl” (Kallivayalil, Levitan, Brown, \& Harvey, 2013, p.272). Consequently, participants also struggled with self-esteem (O'Brien, Henderson \& Bateman, 2007). However, over time, participants' narratives became more complete and they were able to develop and describe a framework for the trauma (Kallivayalil et al., 2013). However, the process of engaging with the trauma was, in itself, distressing: "I can remember finding an identity, finding myself waking up, finding myself heaving in pain” (Phillips \& Daniluk, 2004, p. 180). Therefore, engaging with therapy was not without its difficulties for the participants.

However, an important code that appeared in most of the studies reviewed was that of not being alone: "it [talking therapy] makes me feel that I am not alone, that there is help there when I need it." (Chouliara et al., 2011, p.137). Sometimes, participants described a 
CSA Survivor Experiences of Talking Therapies

sense of finding out more about themselves and a path towards healing through others (KiaKeating, Sorsoli, \& Grossman, 2010). Similarly, empathising with other survivors and developing an external perspective on abuse provided a new context for participants' experiences: “'if they didn't deserve to be abused... maybe I didn't deserve it either'” (LevWiesel, 2000, p.9). It was suggested that group therapy facilitated participants' healing through the stories of others (Arias \& Johnson, 2013); implying connections with others helped participants develop their meaning making processes around their pasts, developing their sense of self.

\section{2: Bigger than one self: stages of healing}

The first stage of healing from the papers reviewed appeared to be a process of recognizing the impact of CSA upon their sense of self; as one participant recalled: "that was so detrimental to self-esteem... self-worth that... feeling of self" (Saha, Chung, \& Thorne, 2011, p.107). Equally, becoming more comfortable with oneself seemed to be important in learning about the self: "before, I couldn’t look myself in the eyes” (Chouliara et al., 2011, p.138).

A second stage that arose from a recurrent code in the studies was that there was a sense for many participants of the self being bigger than one self with different parts, before it seemed possible to become a "complete and whole human being" (Tummala-narra, Kallivayalil, Singer, \& Andreini, 2012, p.646). For example, some participants described a dissociated sense of self, which appeared disconnected from feeling and living: "Am I really inside myself?” (Brown, Kallivayalil, Mendelsohn, \& Harvey, 2012, p.107). This stage may represent how participants encompassed their extreme past experiences through dissociative coping strategies that could gradually be reduced as they processed their experiences. 
Additionally, the sense of there being at least one hidden inside self and another outside self that others saw seemed to be an important coping mechanism for some participants. As participants started to become more aware of their inside and outside selves, a cohesion seemed to form from within. For example, "Just started feeling more like myself as a being in the world instead of living this double identity" (Tummala-narra, Kallivayalil, Singer, \& Andreini, 2012, p.645). This third stage of healing appeared to give participants a way to connect with themselves and others.

Some participants described a multiplicity of the self in that their inner- and outerselves could be very different. This difference influenced how they related to therapists, which led one participant to ask therapists to "look deeper" (McGregor, Thomas, \& Reid, 2006, p.46). Another participant described how: "inside, not that people would see this, I was very, very anxious and very insecure and distressed but outside I was outgoing, sociable" (Saha, Chung, \& Thorne, 2011, p.104). This missing and misunderstanding appeared to enhance participants' anxiety around therapy (O'Brien, Henderson, \& Bateman, 2007, p.5). Crucially, the connections made in therapy appeared to translate to connections outside of therapy too. For instance, one participant described how she felt she could connect her innerself with others following group therapy: "I never told anyone my true feelings [before]" (Tummala-narra, Kallivayalil, Singer, \& Andreini, 2012, p.645).

\section{3: Developing self-kindness and a new sense of self}

Many of the studies identified examples of how therapy enhanced self-kindness, which seemed intrinsically linked to developing self-esteem (Grossman, Sorsoli, \& KiaKeating, 2006; Parker, Fourt, Langmuir, Dalton, \& Classen, 2007; Saha, Chung, \& Thorne, 2011). Kindness and understanding towards others was also sometimes mentioned. One participant who had trained to become a psychologist said of his father who sexually abused him: "He was gang raped when he was about six years old, and when he would abuse me, it 
was a replication of what had happened to him" (Grossman, Sorsoli, \& Kia-Keating, 2006, p.438). The sense of a survivor identity also appeared to hold different amounts of value at varying stages of the participants' healing. For example, one participant described how her survivor identity had evolved: "I think of myself as a woman, an artist" (Phillips \& Daniluk, 2004, p.180). This shift towards having a sense of self not reliant on being a survivor of CSA appeared an important step to finding an independent adult identity and required the process of recognising one's strengths through self-kindness.

Theme 3: Therapeutic Lights and Black Holes in the Shadows of CSA - "He's allowed me to grieve" (Phelps, Friedlander, \& Enns, 1997, p.326)

This third theme discusses specifically how the intra- and interpersonal shadows cast through experiencing CSA affected the participants in therapy and how helpful therapy could facilitate healing: as one participant indicated: "I never made any connection that (the effects were) connected (to the CSA)-Therapy set me free from that... therapy has saved my life." (McGregor, Thomas, \& Reid, 2006, p.49).

\section{1: Specific relational needs}

Participants who could connect positively to themselves, often through developing a positive therapeutic alliance with their therapist or group members (Stige, Træen, \& Rosenvinge, 2013), could develop their self-perspective: "Before I was invisible, even though I wasn't, I felt so invisible. And now I know I'm not invisible. I am a person who has an impact on people" (Phillips \& Daniluk, 2004, p.179). Additionally, when therapists were alert to the specific relational needs of their clients, participants reported this as facilitating them to safely engage in therapy: "people who suffer from any sort of abuse, they need to be told that they have the permission, to... interrupt, the permission to speak out, the permission to say "No" and permission to do what they think is right" (McGregor, Thomas, \& Reid, 2006, p.44). Similarly, normalising distress as a response to trauma, rather than as mental illness 
CSA Survivor Experiences of Talking Therapies

(Harper, Stalker, Palmer, \& Gadbois, 2008; O’Brien, Henderson \& Bateman, 2007), was found to be very helpful: "it put everything in a framework that helped me" (Palmer, Stalker, Gadbois, \& Harper, 2004, p.116).

However, with self-awareness and self-cohesion, the healing of the self for many still seemed incomplete, as one participant described: "there is like fear and revulsion but not the immobilizing kind” (Edmond, Sloan, \& McCarty, 2004, p.266). Many described relating to themselves as hard too: "The most difficult part was to be confronted with yourself... the things that happened during the treatment within yourself' (Stige, Rosenvinge, \& Træen, 2013, p.424).

\subsection{Stumbling in the dark and repeating abusive dynamics}

When non-specialised therapists were unable to meet the needs of their clients, they were sometimes likened to "stumbling in the dark" (McGregor, Thomas, \& Reid, 2006, p.48). Depending upon how the 'stumbling' was managed, some data suggested that if therapists sought additional help when they felt under-resourced, participants could view this as helpful, perhaps also modelling seeking support: "he was just so open to making another connection and bringing someone else in, and working with someone else, like as a team" (Harper,

Stalker, Palmer, \& Gadbois, 2008, p.369).

Replaying the dynamics of past abusive relationships was also a factor that participants had to face. For example, as one participant described: "I felt overpowered... Like, I've got to do what this parental person says, and he's the professional... I felt like my power was taken away almost forcefully" (Koehn, 2007, p.47). The use of touch in the relationship was also a very delicate therapeutic process and both positive and negative experiences were found; this was in terms of touch being "really significant and important" (Phelps, Friedlander, \& Enns, 1997, p.327) or not "safe to pursue" (p.328). As one participant 
described choice: "she [therapist] had a wonderful holistic approach and we integrated all of that stuff." (McGregor, Thomas, \& Reid, 2006, p.47).

Other aspects of therapy that participants reported finding very challenging related to not following the client's wishes around how to undertake the therapy (Koehn, 2007) and not including the multiplicity that so many people discussed, be it having an outer-self or dissociative identity disorder (DID; Palmer, Stalker, Harper, \& Gadbois, 2007). However, when participants felt safe within the relationship and therefore able to talk about the abuse, they reported finding this disclosure and being heard very healing: "We bonded in a way on a personal level so it made it easier for me to disclose a lot of really horrible things about the abuse" (Edmond, Sloan, \& McCarty, 2004, p.265). This may be reminiscent of the interpersonal unpredictability that CSA survivors can experience, which makes knowing the therapist an important part of the process to reduce the perception of threat for the client.

\section{3: Endings, loss, and grief}

When therapy ended, particularly the group therapy programmes, new difficulties arose for the participants as they missed the support (Anderson \& Hiersteiner, 2008; O'Brien, Henderson \& Bateman, 2007; Parker, Fourt, Langmuir, Dalton, \& Classen, 2007). One participant described the ending of her therapy group as "like jumping off a train" as she felt unsupported (Harper, Stalker, Palmer, \& Gadbois, 2008, p.366). Such findings further suggest some of the shadows of loss: loss of support as well as loss of connections and safety.

Other shadows of loss included grief for lost time and experiences, which emerged from therapy (O'Brien, Henderson, \& Bateman, 2007; Phelps, Friedlander, \& Enns, 1997). For example, "I never really thought of [her abusive childhood] as a loss, but it was" (Palmer, Stalker, Gadbois, \& Harper, 2004, p.116). Other participants took a transgenerational perspective upon loss and looked to the next generation for healing: "The damage is probably 
too extensive... certainly within this generation, and that's very sad" (Phillips \& Daniluk, 2004, p.181). However, some participants had managed to heal their wounds enough to find what they wanted: "I decided to succeed in both my marriage and my work, and I did. I am quite satisfied with my life', (Lev-Wiesel, 2000, p.8-9).

Theme 4: Healing or Harrowing: connecting and first time experiences - "I might never have known how unlimited the human spirit is around finding its way through impossible odds" (Phillips \& Daniluk, 2004, p.182).

Within the studies reviewed were prominent codes around connecting with others and feeling a sense of togetherness through therapy (Parker, Fourt, Langmuir, Dalton, \& Classen, 2007; Stige, Rosenvinge, \& Træen, 2013; Tummala-narra, Kallivayalil, Singer, \& Andreini, 2012). As one participant explained: "encouragement thread from one to another" (Saha, Chung, \& Thorne, 2011, p.108).

\section{1: Experiencing connecting and sharing}

Finding strength through hearing other survivors was mentioned in several studies (Arias \& Johnson, 2013; Chouliara et al., 2013; O'Brien, Henderson, \& Bateman, 2007; Palmer, Stalker, Gadbois, \& Harper, 2004), for instance "finding other women that had a voice... there is an acceptance here, there is a warmth and compassion that I never knew could possibly exist" (Anderson \& Hiersteiner, 2008, p.421). Additionally, experiencing warmth and understanding within relationships was important for healing (Arias \& Johnson, 2013; Phillips \& Daniluk, 2004). Developing perspective through connecting with others' experiences appeared to give the trauma a context as well as the survivor a platform for their healing.

Conversely, there were examples within the data in which the hearing of other's stories would be detrimental to healing, although a degree of understanding and perspective was still 
CSA Survivor Experiences of Talking Therapies

apparent (Parker, Fourt, Langmuir, Dalton, \& Classen, 2007). Hearing others' stories could be challenging: "it has been hard at times to find sympathy for those I listen to, because I have experienced so much" (Stige, Rosenvinge, \& Træen, 2013, p.1300). Alternatively, some participants described how they felt ready to engage with services, although they were told that they were "considered too complex" for talking therapy (Chouliara et al., 2011, p.143) or "not ready yet" if a particular approach to therapy was not successful, which was reported as “invalidating, like you are not worthy of recovery" (O'Brien, Henderson \& Bateman, 2007, p.6).

\subsection{Experiential learning and change}

The development of a safe space appeared to be highly reliant on the creation of appropriate and sensitive boundaries (Chouliara et al., 2011; Harper, 2006; O'Brien, Henderson, \& Bateman, 2007; Parker, Fourt, Langmuir, Dalton, \& Classen, 2007). Participants explained how when they felt highly distressed, they were unable to use the tools helpfully (Palmer, Stalker, Gadbois, \& Harper, 2004; Parker, Fourt, Langmuir, Dalton, \& Classen, 2007). As one participant explained: "I think the single most helpful thing with [my therapist] was defining a relationship that had boundaries and then experientially learning that there are people capable of maintaining those boundaries" (Kia-Keating, Sorsoli, \& Grossman, 2010, p.676). Boundaries appeared to be important for two main reasons: firstly, to establish the therapeutic relationship as safe; and secondly, to help the participants facilitate their healing outside of therapy (Tummala-narra, Kallivayalil, Singer, \& Andreini, 2012). Perhaps due to the violation of the participants' boundaries in the past, boundaries and safety appeared synonymous in the relationship.

In further relation to learning and using tools, some participants were able to recognise the strengths and skills they had developed: "I've survived it and because of that... I have learnt a lot of skills" (Phillips \& Daniluk, 2004, p.181). However, when new coping 
CSA Survivor Experiences of Talking Therapies

strategies started failing, some participants found they started struggling quickly: "I lost my parachute... I was free falling" (Stige, Træen, \& Rosenvinge, 2013, p.1301). The process of helping participants find other parachutes when their own failed seemed again to lie in the therapeutic alliance (O'Brien, Henderson, \& Bateman, 2007; Phelps, Friedlander, \& Enns, 1997; Stige, Rosenvinge, \& Træen, 2013). When the participants recognised their own strengths in accordance with, but not reliant on their therapist's abilities, they were able to identify their own skills: "I wouldn't crumble without him [therapist]" (Phelps, Friedlander, \& Enns, 1997, p.326).

Finally, findings suggested that talking about choice and control may not be enough and that the survivor needed to experience having control before they could truly understand that they did not have control or choice as a child: "as a child didn't have the power to stop anything or change anything, so it wasn't my fault" (Parker, Fourt, Langmuir, Dalton, \& Classed, 2007, p.66). It may have been that this contrast in experiencing what it felt like to have choice and control facilitated this change in perspective and thus the process of healing (Grossman, Sorsoli, \& Kia-Keating, 2006; Harper, 2006; Harper, Stalker, Palmer, \& Gadbois, 2008).

\subsection{The language in talking therapy}

Within the data from the studies reviewed was a large collection of codes relating specifically to how the participants experienced using language within talking therapy to talk about abuse, themselves, and recovery. The participants' quotes from the studies suggested that participants could still find it difficult to articulate certain feelings: "I wanna say, I want to say, my anger wants to say they were bastards, they were evil bastards. But my more balanced side says that they were sick" (Kallivayalil, Levitan, Brown, \& Harvey, 2013, p.276). As another participant suggested: “aren’t words useless sometimes!!" (Chouliara et al., 2011, p.139). For some participants, it seemed as though they had never developed the 
CSA Survivor Experiences of Talking Therapies

language for their experiences: "I couldn't tell my story... with the sexual abuse... you don't have words for it..." (Palmer, Stalker, Gadbois, \& Harper, 2004, p.116).

One of the reasons talking seemed to be so difficult for the participants was that so many of them had been kept silent for so long (Chouliara et al., 2011; Saha, Chung, \& Thorne, 2011; Stige, Rosenvinge, \& Træen, 2013). However, despite the difficulties surrounding finding words, disclosing the abuse appeared to be an important first step in starting to understand their experiences (Arias \& Johnson, 2013). One participant explained "breaking the silence... about what you feel and think, or have experienced... can sometimes feel overwhelming" (Palmer, Stalker, Gadbois, \& Harper, 2004, p.115). For others, talking about what happened reduced some of the power of the abuser: "it helped me, after that I stopped hearing my abuser's voice" (Saha, Chung, \& Thorne, 2011, p.108).

\section{Discussion}

The current synthesis provides a number of findings from the perspectives of CSA survivors who have experienced talking therapies. Firstly, the experience of healing was discussed as a largely ongoing process, which could be facilitated through developing trust, safety, equality, and finding connections with others and discovering hope for the future. Although relational aspects of the therapeutic alliance are recognised as important with many client groups in terms of the therapeutic process and outcome (Mikulincer, Shaver, \& Berant, 2013), survivors of CSA appeared to need the specific relational experiences described in this review to move towards recovery.

Herman suggests: "it should be possible to recognize a gradual shift from unpredictable danger to reliable safety, from dissociated trauma to acknowledged memory, and from stigmatized isolation to restored social connection" (1992, p.155). The current synthesis helps explain how the nuanced mechanisms of positive therapeutic processes 
facilitated healing. Mechanisms included having the safety and freedom to find words for trauma; to safely say those words aloud and for them to be witnessed through belief; to have therapeutic space for the parts of the self to move and express themselves at different rates, so as to develop a narrative that incorporated past abuse with a present ability to experience real choice and control.

Additionally, it was essential for participants to develop enough trust with the innerand outer-self and with others, so that intra- and interpersonal connections could be made. Finally, changing perspectives of the self and others could facilitate healing towards a cohesive whole adult self, independent from the trauma of the past. Although it is recognised that the initial stages of therapeutic work with survivors should not focus on past traumas so as not to re-traumatise the client (e.g. Chouliara et al., 2011; Dillon, Johnstone, \& Longden, 2012), the current synthesis suggested that from the survivor's perspective, the process of getting to know the therapist was crucial for finding safety and reducing the anticipated threat of further abuse. In summary, the interpersonal approach of the therapist appeared more important to the process of healing than the therapeutic modality.

Additionally, a novel finding emerging from the synthesis was that there appeared to be five distinctive stages of therapeutic change in relation to the developing self that, if managed well by the therapist, could facilitate healing and ongoing change. For example, the stages appeared to firstly link past experiences of CSA with current distress, accepting the impact of CSA and then becoming more comfortable in recognising that the self may have had to become bigger than one to encompass the abused past self and comparably wellfunctioning present self. Following this process, forming intrapersonal connections and integrating trauma histories through the ways discussed throughout theme two appeared to help participants connect to themselves and others, which further facilitated their own selfcohesion and healing. This third stage seemed to be when a survivor identity appeared most 
CSA Survivor Experiences of Talking Therapies

helpful. Fourthly, once a stronger sense of self had developed, self-kindness was increasingly possible, which could facilitate the development of self-esteem. Finally, the development of a self-governing sense of self, independent from CSA, appeared to be the final step away from a survivor identity towards a "whole" adult self. Consequently, the mechanisms of change that Ehlers et al. (2010) suggested we need to understand better appeared largely intrapersonal in nature.

Although the processes identified in this synthesis are unique as they formed as a result of an in-depth synthesis, this phased approach towards integrating "fragmented experience into a meaningful autobiographical narrative" within the context of a secure and trusting therapeutic relationship, is concurrent with other theoretical (Dillon, Johnstone, \& Longden, 2012, p.151) and empirical recommendations for supporting survivors through therapy (Arias \& Johnson, 2013; Bicknell-Hentges \& Lynch, 2009; Brown, Kallivayalil, Mendelsohn, \& Harvey, 2012; Chouliara et al., 2011; Koehn, 2007; McGregor, Thomas, \& Read, 2006; Phillips \& Daniluk 2004). This synthesis would further suggest that facilitating the client to choose the direction of therapy, rather than following a modality, can help the client experience having choice and control, which was found to be pivotal for healing.

Lastly, despite the efforts to incorporate all relevant empirical studies, this systematic review encompasses several limitations. This synthesis considered CSA in a broad sense, which is likely to have influenced the interpretation of the data at the original and synthesis levels. However, it was considered important to include as many participant voices as possible in the review and represent the context of multi-type maltreatment through which CSA often exists. Furthermore, the idiographic nature of the review meant that selected quotes could be considered to represent CSA survivors' experiences in particular, leading to an enhanced CSA focused analysis. Finally, due to the relatively limited cultural diversity across the studies, future research should aim to explore the role of different cultures upon 
CSA Survivor Experiences of Talking Therapies

relational experiences in therapy and how culture may influence meaning making processes throughout healing. Specifically, as the construct of the self varies across cultures (Castillo, 1997), it would be interesting to know more about how different perceptions of the self influence some of the intrapersonal processes discussed throughout this review.

\section{Conclusion}

The current synthesis combines the findings from empirical studies that span a range of survivor experiences of talking-therapy, from initial impressions to completing their journey through therapy. Within the accounts emerged some significant new indications as to what survivors require from talking therapies, such as the experiential learning of choice and control, finding a framework for the trauma, and recognising their strengths. 
CSA Survivor Experiences of Talking Therapies

\section{Acknowledgments}

The authors would like to thank all the authors of the reviewed studies who provided further details of their work and encouragement throughout this process, particularly Dr Sally Palmer and Dr Zoë Chouliara. The authors would especially like to thank Dr Mike Lloyd for his valuable feedback and support during this study.

Disclosure of Interest: The authors have no disclosures to make.

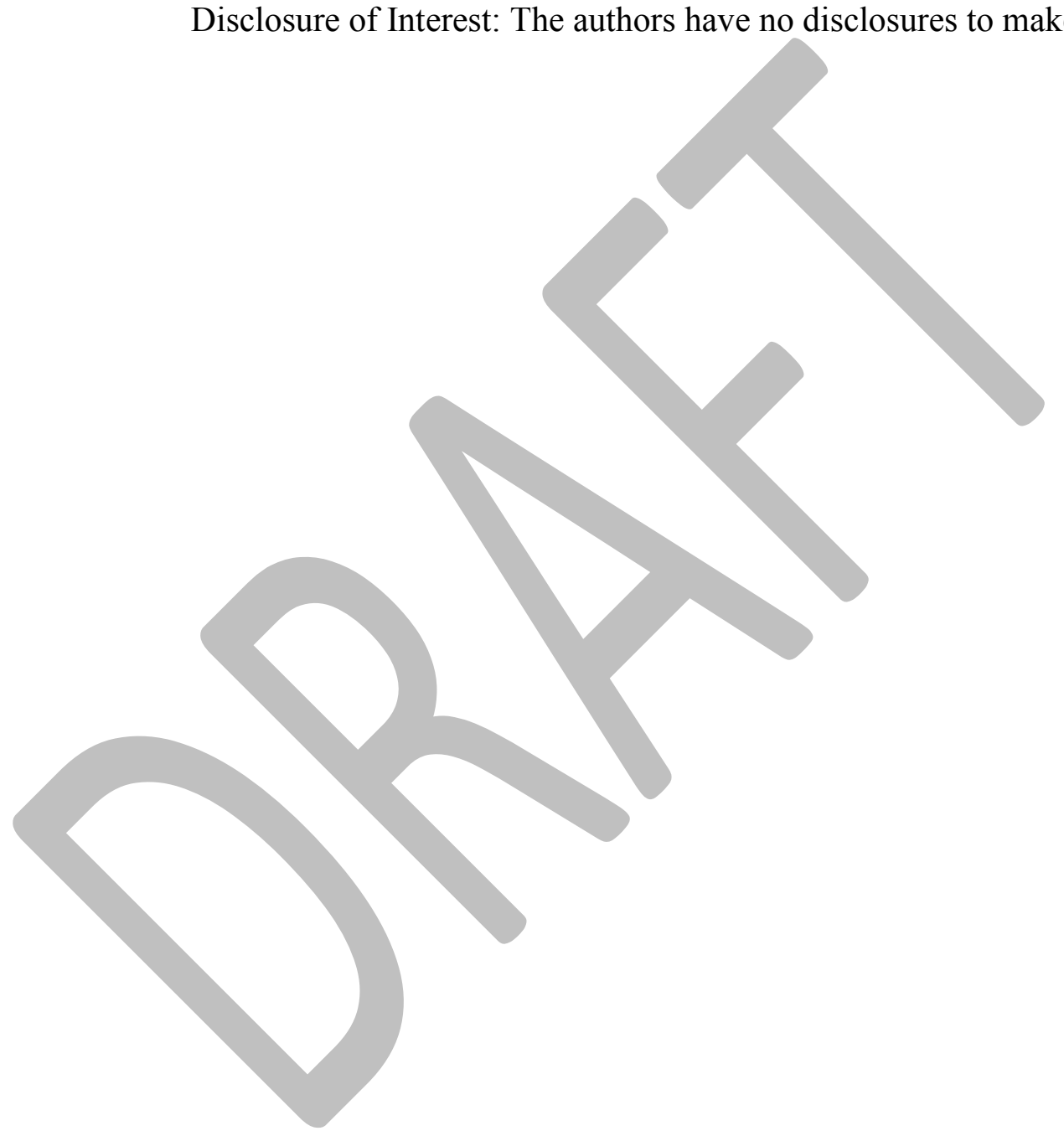


CSA Survivor Experiences of Talking Therapies

\section{References}

*Anderson, K., \& Hiersteiner, C. (2008). Recovering From Childhood Sexual Abuse: Is a "Storybook Ending" Possible? American Journal Of Family Therapy, 36(5), 413-424. doi: $10.1080 / 01926180701804592$

*Arias, B. J, \& Johnson, C.V. (2013). Voices of Healing and Recovery from Childhood Sexual Abuse. Journal of Child Sexual Abuse, 22(7), 822-841. doi: $10.1080 / 10538712.2013 .830669$

Banyard, V., Williams, L., \& Siegel, J. (2001). The Long-Term Mental Health Consequences of Child Sexual Abuse: An Exploratory Study of the Impact of Multiple Traumas in a Sample of Women. Journal of Traumatic Stress, 14(4), 697-715. doi: 10.1023/A:1013085904337

Bicknell-Hentges, L., \& Lynch, J.J. (2009). Everything counselors and supervisors need to know about treating trauma. Paper based on a presentation at the American Counseling Association Annual Conference and Exposition, Charlotte, NC. Retrieved from: http://webcache.googleusercontent.com/search?q=cache:No0IjZITuZ4J:https://www.co unseling.org/docs/disaster-and-trauma_sexual-abuse/everything-counselors-andsupervisors-need-to-know-about-treating-trauma_bicknell-hentgeslynch.doc\%3Fsfvrsn $\% 3 \mathrm{D} 2+\& \mathrm{~cd}=6 \& \mathrm{hl}=\mathrm{en} \& \mathrm{ct}=\mathrm{clnk} \& \mathrm{gl}=\mathrm{uk}$

Briere, J. (1992). Child abuse trauma: theory and treatment of the lasting effects. Newbury Park, Calif: Sage Publications ISBN 0803937121

*Brown, N.R., Kallivayalil, D., Mendelsohn, M., \& Harvey, M.R. (2012). Working the Double Edge: Unbraiding Pathology and Resiliency in the Narratives of EarlyRecovery Trauma Survivors. Psychological Trauma: Theory, Research, Practice, and Policy 4(1), 102-111. doi: 10.1037/a0024969 
CSA Survivor Experiences of Talking Therapies

Castillo, R.J. (1997). Dissociation. In Culture and Psychopathology: A Guide to Clinical Assessment. Edited by W. S. Tseng \& J. Streltzer (pp. 101-123). New York: Brunner/Mazel. ISBN: 9780876308394

Chouliara, Z., Karatzias, T., Scott-Brien, G., Macdonald, A., MacArthur, J., \& Frazer, N. (2012). Adult survivors' of childhood sexual abuse perspectives of services: A systematic review. Counselling and Psychotherapy Research, 12(2), 146-161. doi: $10.1080 / 14733145.2012 .656136$

*Chouliara, Z., Karatzias, T., Scott-Brien, G., Macdonald, A., MacArthur, J., \& Frazer, N. (2011). Talking Therapy Services for Adult Survivors of Childhood Sexual Abuse (CSA) in Scotland: Perspectives of Service Users and Professionals. Journal of Child Sexual Abuse, 20(2), 128-156. doi: $10.1080 / 10538712.2011 .554340$

Critical Appraisal Skills Programme (2013). CASP Qualitative Checklist. Retrieved from: http://media.wix.com/ugd/dded87_29c5b002d99342f788c6ac670e49f274.p df

Dillon, J., Johnstone, L., \& Longden, E. (2012). Trauma, Dissociation, Attachment \& Neuroscience: A new paradigm for understanding severe mental distress. The Journal of Critical Psychology, Counselling and Psychotherapy, 145-155. doi: 1471$7646 / 12 / 03145-11$

Draucker, C.B., Martsolf, D.S., Ross, R., Cook, C.B., Stidham, A.W., \& Mweemba, P. (2009). The essence of healing from sexual violence: A qualitative metasynthesis. Research in Nursing \& Health, 32(4), 366-378. doi: 10.1002/nur.20333 
CSA Survivor Experiences of Talking Therapies

*Edmond, T., Sloan, L., \& McCarty, D. (2004). Sexual Abuse Survivors' Perceptions of the Effectiveness of EMDR and Eclectic Therapy. Research on Social Work Practice, 14(4), 259-272. doi: 10.1177/1049731504265830

Ehlers, A., Bisson, J., Clark, D.M., Creamer, M., Pilling, S., Richards, D., Schnurr, P.P., Turner, S., \& Yule, W. (2010). Do all psychological treatments really work the same in posttraumatic stress disorder? Clinical Psychology Review, 30(2), 269-276. doi: 10.1016/j.cpr.2009.12.001

Ehring, T., Welboren, R., Morina, N., Wicherts, J.M., Freitag, J., \& Emmelkamp, P.M.G. (2014). Meta-analysis of psychological treatments for posttraumatic stress disorder in adult survivors of childhood abuse. Clinical Psychology Review, 34(8), 645-657. doi: 10.1016/j.cpr.2014.10.004

Finkelhor, D., Hotaling, G., Lewis, I.A., \& Smith, C. (1990). Sexual abuse in a national survey of adult men and women: Prevalence, characteristics, and risk factors. Child Abuse \& Neglect, 14(1), 19-28. doi: 10.1016/0145-2134(90)90077-7

Gill, S. (2010). The Therapist as Psychobiological Regulator: Dissociation, Affect Attunement and Clinical Process. Clinical Social Work Journal, 38(3), 260-268. doi: $10.1007 / \mathrm{s} 10615-009-0213-5$

Gomersall, T., Madill, A., Summers, L.K.M. (2011). A metasynthesis of the self-management of type 2 diabetes. Qualitative health research, 21(6), 853-71. doi: $10.1177 / 1049732311402096$

*Grossman, F.K., Sorsoli, L., \& Kia-Keating, M. (2006). A gale force wind: Meaning making by male survivors of childhood sexual abuse. American Journal of Orthopsychiatry, 76(4), 434-444. doi: 10.1037/0002-9432.76.4.434 
CSA Survivor Experiences of Talking Therapies

Harden, A., \& Thomas, J. (2008). Methods for the thematic synthesis of qualitative research in systematic reviews. BMC Medical Research Methodology, 8(1), 45. Doi: $10.1186 / 1471-2288-8-45$

*Harper, K. (2006). Negotiating Therapeutic Boundaries with Childhood Sexual Abuse Survivors: Choices in Decision-Making. Stress, Trauma, and Crisis, 9(2), 95-117. doi: $10.1080 / 15434610600683791$

* Harper, K., Stalker, C.A., Palmer, S., \& Gadbois, S. (2008). Adults traumatized by child abuse: What survivors need from community-based mental health professionals. Journal of Mental Health 17(4), 361-374. doi 10.1080/09638230701498366

Herman, J.L. (1992). Trauma and Recovery. New York: Basic Books. ISBN: 0465087302 Hetzel-Riggin, M.D., Brausch, A. M., \& Montgomery, B.S. (2007). A Meta-Analytic Investigation of Therapy Modality Outcomes for Sexually Abused Children and Adolescents: An Exploratory Study. Child Abuse \& Neglect: The International Journal, 31(2), 125-141. PMID: 17306369

Higgins, D.J., \& Mccabe, M.P. (2001). The Development of the Comprehensive Child Maltreatment Scale. Journal of Family Studies, 7(1), 7-28. doi: 10.5172/jfs.7.1.7

International Society for the Study of Trauma and Dissociation. (2011). [Chu, J. A., Dell, P. F., Van der Hart, O., Cardeña, E., Barach, P.M., Somer, E., Loewenstein, R.J., Brand, B., Golston, J.C., Courtois, C.A., Bowman, E.S., Classen, C., Dorahy, M., , Sar,V., Gelinas,D.J., Fine,C.G., Paulsen, S., Kluft, R.P., Dalenberg, C.J., Jacobson-Levy, M., Nijenhuis, E.R.S., Boon, S., Chefetz, R.A., Middleton, W., Ross, C.A., Howell, E., Goodwin, G., Coons, P.M., Frankel, A.S., Steele, K., Gold, S.N., Gast, U., Young, L. M., \& Twombly, J.]. Guidelines for treating dissociative identity disorder in adults, 
CSA Survivor Experiences of Talking Therapies

third revision. Journal of Trauma \& Dissociation, 12, 115-187. doi:

$10.1080 / 15299732.2011 .537247$

*Kallivayalil, D., Levitan, J., Brown, N., \& Harvey, M.R. (2013). Preliminary Findings from a Qualitative Study of Trauma Survivors in Treatment: Changes in Personal Narratives. Journal of Aggression, Maltreatment \& Trauma, 22(3), 262-281. doi:

$10.1080 / 10926771.2013 .743942$

Kendall-Tackett, K.A., Williams, L.M., \& Finkelhor, D. (2001). Impact of sexual abuse on children: A review and synthesis of recent empirical studies. In R. Bull (Ed.), Children and the law: The essential readings (pp. 29-76). Malden, MA: Blackwell. doi: 10.1108/rr.2002.16.1.9.5

*Kia-Keating, M., Sorsoli, L., \& Grossman, F. K. (2010). Relational Challenges and Recovery Processes in Male Survivors of Childhood Sexual Abuse. Journal of Interpersonal Violence, 25(4), 666-683. doi: 10,1177/0886260509334411

*Koehn, C.V. (2007). Women's Perceptions of Power and Control in Sexual Abuse Counseling. Journal of Child Sexual Abuse, 16(1), 37-60. doi: 10.1300/J070v16n01_03

Lev-Wiesel, R. (2008). Beyond Survival: Growing Out of Childhood Sexual Abuse, in Trauma, Recovery, and Growth: Positive Psychological Perspectives on Posttraumatic Stress (eds S. Joseph and P. A. Linley), John Wiley \& Sons, Inc., Hoboken, NJ, USA. doi: $10.1002 / 9781118269718 . \operatorname{ch} 8$

*Lev-Wiesel, R. (2000). Quality of Life in Adult Survivors of Childhood Sexual Abuse Who Have Undergone Therapy. Journal of Child Sexual Abuse, 9(1), 1-13. doi: 10.1300/J070v09n01_01 
CSA Survivor Experiences of Talking Therapies

Maniglio, R. (2009). The impact of child sexual abuse on health: A systematic review of reviews. Clinical Psychology Review, 29(7), 647-657. doi: 10.1016/j.cpr.2009.08.003

McAlpine, S.J., \& Shanks, A. (2010). Self-concept and attributions about other women in women with a history of childhood sexual abuse. Clinical Psychology \& Psychotherapy, 17(3), 196-210. doi: 10.1002/cpp.671

*McGregor, K., Thomas, D.R., \& Read, J. (2006). Therapy for Child Sexual Abuse: Women Talk About Helpful and Unhelpful Therapy Experiences. Journal of Child Sexual Abuse, 15(4), 35-59. doi: 10.1300/J070v15n04_03

Mikulincer, M., Shaver, P.R., \& Berant, E. (2013). An Attachment Perspective on Therapeutic Processes and Outcomes. Journal of Personality, 81(6), 606-616. Doi: 10.1111/j.1467-6494.2012.00806.x

Nelson, S., \& Phillips, S. (2001). Beyond trauma: Mental health care needs of women who have survived childhood sexual abuse. The University of Edinburgh. Edinburgh Association for Mental Health.

*O'Brien, L., Henderson, C., \& Bateman, J. (2007). Finding a place for healing: Women survivors of childhood sexual abuse and their experience of accessing services. Mental Health, 6(2), 91-100. doi: 10.5172/jamh.6.2.91

Olio, K. (1989). Memory retrieval in the treatment of adult survivors of sexual abuse. Transactional Analysis Journal, 19(2), 93-100.

Olio, K.A., \& Cornell, W.F. (1993). The Therapeutic Relationship As The Foundation for Treatment with Adult Survivors of Sexual Abuse. Psychotherapy: Theory, Research, Practice, Training, 30(3), 512-523. Retrieved from:

http://kspope.com/memory/relationship.php\#copy 
CSA Survivor Experiences of Talking Therapies

*Palmer, S., Stalker, C., Gadbois, S., \& Harper, K. (2004). What Works for Survivors of Childhood Abuse: Learning From Participants in an Inpatient Treatment Program. American Journal of Orthopsychiatry, 74(2), 112-121. doi: 10.1037/00029432.74 .2 .112

*Palmer, S., Stalker, C., Harper, K., \& Gadbois, S. (2007). Balancing Positive Outcomes with Vicarious Traumatization: Participants' Experiences with Group Treatment for LongTerm Effects of Childhood Abuse. Social Work with Groups, 30(4), 59-77. doi: 10.1300/J009v30n04_05

*Parker, A., Fourt, A., Langmuir, J.I., Dalton, E.J., \& Classen, C.C. (2007). The Experience of Trauma Recovery: A Qualitative Study of Participants in the Women Recovering from Abuse Program (WRAP). Journal of Child Sexual Abuse, 16(2), 55-77. doi: $10.1300 / J 070 v 16 \mathrm{n} 024$

*Phelps, A., Friedlander, M.1., \& Enns, C. (1997). Psychotherapy process variables associated with the retrieval of memories of childhood sexual abuse: A qualitative study. Journal of Counseling Psychology, 44(3), 321-332. ISSN: 0022-0167

*Phillips, A., \& Daniluk, J.C. (2004). Beyond "Survivor": How Childhood Sexual Abuse Informs the Identity of Adult Women at the End of the Therapeutic Process. Journal of Counseling \& Development, 82(2), 177-184. doi: 10.1002/j.1556-6678.2004.tb00299.x

Price-Robertson, R., Rush, P., Wall, L., \& Higgins, D. (2013). Rarely an Isolated Incident: Acknowledging the Interrelatedness of Child Maltreatment, Victimisation and Trauma. (Child and Family Community Australia, Paper No. 15). Melbourne: Child Family Community Australia, Australian Institute of Family Studies. doi: 10.1037/e567272013-001 
CSA Survivor Experiences of Talking Therapies

Rice, M. J. (2008). Evidence-Based Practice in Psychiatric and Mental Health Nursing: Qualitative Meta-Synthesis. Journal of the American Psychiatric Nurses Association, 14( 5), 382-385. doi: 10.1177/1078390308326661

Richmond, J.M., Elliott, A.N., Pierce, T.W., Aspelmeier, J.E., \& Alexander, A.A. (2009). Polyvictimization, Childhood Victimization, and Psychological Distress in College Women. Child Maltreatment, 14(2), 127-147. doi: 10.1177/1077559508326357

*Saha, S., Cheung Chung, M., \& Thorne, L. (2011). A narrative exploration of the sense of self of women recovering from childhood sexual abuse. Counselling Psychology Quarterly, 24(2), 101-113. doi: 10.1080/09515070.2011.586414

Sandelowski, M., Barroso, J., \& Voils, C.I. (2007). Using qualitative metasummary to synthesize qualitative and quantitative descriptive findings. Research in Nursing \& Health, 30(1), 99-111. doi: 10.1002/nur.20176

*Stige, S.H., Rosenvinge, J.H., \& Træen, B. (2013). A meaningful struggle: Trauma clients' experiences with an inclusive stabilization group approach. Psychotherapy Research, 23(4), 419-429. doi: 10.1080/10503307.2013.778437

*Stige, S.H., Træen, B., \& Rosenvinge, J.H. (2013). The Process Leading to Help Seeking Following Childhood Trauma. Qualitative Health Research, 23(10), 1295-1306. doi: $10.1177 / 1049732313503907$

*Tummala-Narra, P., Kallivayalil, D., Singer, R., \& Andreini, R. (2012). Experiences of Complex Trauma Survivors in Treatment: Preliminary Findings From a Naturalistic Study. Psychological Trauma: Theory, Research, Practice, and Policy, 4(6), 640-648. doi: $10.1037 / \mathrm{a} 0024929$

Ullman, S.E. (2015). Sexual revictimization, PTSD, and problem drinking in sexual assault survivors. Addictive behaviors. 53, 7-10. doi:10.1016/j.addbeh.2015.09.010 